\title{
The musculoskeletal effect of intense physical training of non-athletic youth corps conscripts
}

\author{
M O Egwu
}

\begin{abstract}
Objective-To determine the musculoskeletal problems associated with high intensity physical exercise among nonathletic youth subjects.

Methods-484 fresh Nigerian graduates participating in the mandatory National Youth Service Corps (NYSC) programme were studied. At the start of the four week intensive physical training which formed part of the orientation course for the programme, the subjects completed a questionnaire designed to determine their previous exercise habit. The physical training consisted of jogging, physical drills, games (soccer and volleyball), and man o'war activities. During the period of physical training, the subjects were instructed to report all ailments to the camp clinic.

Results-Muscular pain/soreness and injuries were major problems associated with the exercise. The lower limbs were most affected and the ankle joint was found to be more injury-prone than other joints.

Conclusions-Most of these graduates were physically unfit and the intense fitness programme produced adverse effects on their physical health. Precamp physical preparation would be desirable.

(Br F Sports Med 1996;30:112-115)
\end{abstract}

Key terms: youth; physical training; physical fitness; myalgia; injuries; questionnaire

It has been reported that improper training techniques, poor equipment and biomechanical/ anthropometric abnormalities are the major factors predisposing athletes to injury. ${ }^{12}$ Information on injuries sustained during exercise in young athletes may be obtained from many reports. ${ }^{3-5}$ Some injuries have been reported among untrained youth subjects. ${ }^{6}$ However, information on the patterns of injury and other musculoskeletal problems such as pain and discomfort among non-athletic youths is not widely available.

In Nigeria, fresh graduates of institutions of higher learning (universities, polytechnics, etc) who are below 30 years of age have to participate in a one-year programme referred to as the National Youth Service Corps (NYSC). At the start of each service year, participants are camped and subjected to a four-week orientation course which features intense physical fitness training among other activities. This study was carried out to determine the effects of the various types of exercise embarked upon during this course on the musculoskeletal systems of these non-athletic youths in the orientation camp.

\section{Methods}

The study was conducted between 3 and 31 November 1992, at the beginning of the 1992/93 service year of the NYSC in Maiduguri in Nigeria's northeastern State of Borno. On entry to the camp, all the participants were given a questionnaire designed to determine their precamp exercise status. Of the total of 508 participants, 484 (332 males and 152 females [26.8 (SD 2.79) years old]) completed and returned the questionnaires and thus formed the subjects for the study.

Camp participants with past injuries or congenital anomalies relating to their musculoskeletal system, camp officials, and those who did not take part in the camp physical training were excluded. The subjects went through the military-type non-graduated physical exercises, drills, games (soccer and volley ball), and man o'war activities for four weeks, like the other camp participants. For the duration of the camp, all participants had similar kit, lived a regimented life, and were fed centrally.

The subjects were routinely interviewed and examined weekly and were also instructed to report any ailment or discomfort to the camp clinic. In the clinic, record was made of any injury or ailment.

A total of 434 musculoskeletal disorders was recorded, 300 from males and 234 from females. Subjects who complained of musculoskeletal pain not due to injury were requested to rate their perceived pain and discomfort on a 10 point scale (table 1 ).

\section{Results}

PAST EXERCISE LEVEL

The result of this study showed that of the 484 subjects, 360 ( $74 \%$; 220 males and 140 females) had never partaken in organised sports or physical training. Eighty five $(17 \cdot 6 \%$; 81 males and four females) had not participated in physical exercise for at least the past four years. Thirty $(6 \cdot 7 \% ; 22$ males and eight females) had

Table 110 point scale for rating of perceived pain/discomfort, adapted from Balogun. ${ }^{7}$

\footnotetext{
No pain/discomfort at all

Very very mild

Very mild

Moderate

Very uncomfortable

Unbearable

Excruciating
} 
Table 2 Pre-camp exercise status of the 484 subjects.

\begin{tabular}{|c|c|c|c|c|c|c|c|c|c|c|c|}
\hline \multicolumn{3}{|c|}{$\begin{array}{l}\text { Have not participated in physical } \\
\text { exercise for life }\end{array}$} & \multicolumn{3}{|c|}{$\begin{array}{l}\text { Have not participated in physical } \\
\text { exercise for the past } 4 \text { years }\end{array}$} & \multicolumn{3}{|c|}{ Participate in recreational exercise } & \multicolumn{3}{|c|}{ University athletes } \\
\hline Male & Female & Total & Male & Female & Total & Male & Female & Total & Male & Female & Total \\
\hline $\begin{array}{l}220 \\
45 \cdot 5 \%\end{array}$ & $\begin{array}{l}140 \\
28 \cdot 9 \%\end{array}$ & $\begin{array}{l}360 \\
74 \cdot 4 \%\end{array}$ & $\begin{array}{l}81 \\
16 \cdot 8 \%\end{array}$ & $\begin{array}{l}4 \\
0 \cdot 8 \%\end{array}$ & $\begin{array}{l}85 \\
17 \cdot 6 \%\end{array}$ & 22 & $\begin{array}{l}8 \\
1 \cdot 7 \%\end{array}$ & ${ }^{30} 6 \cdot 2 \%$ & $\begin{array}{l}9 \\
1 \cdot 8 \%\end{array}$ & $\overline{-}$ & $\stackrel{9}{1 \cdot 8 \%}$ \\
\hline
\end{tabular}

participated in leisure exercises, while only nine ( $1.8 \%$; all males) were (non-elite) University level athletes. This is shown in table 2 .

MUSCULAR PAIN

Within the four weeks of physical training, myalgia $(66 \cdot 8 \%)$ was significantly more predominant than painful joints $(33 \cdot 2 \%)$. The highest recorded incidence of pain was in the first week, while the lowest was recorded in the third and fourth weeks. Generally, the incidence of pain (muscle and joint) was relatively higher in the females [134 $(100 \%)]$, than in the males $[156(52 \%)]$. Incidence of muscle pain was highest in the calf muscles $(46.9 \%)$. The incidence of pain in the other muscle groups was as follows: quadriceps $25 \cdot 2 \%$, hamstrings $25 \cdot 2 \%$, back extensors $2 \cdot 7 \%$ (tables 3 and 4 ).

PAINFUL JOINTS

Joint pain was most commonly reported in the ankle $(72 \cdot 2 \%)$. Other affected joints included

Table 3 The influence of adaptation on the weekly distribution of pain in non-athletic youth corpers following intense physical training.

\begin{tabular}{lccclc}
\hline Location of pain & 1st Week & 2nd Week & 3rd Week & 4th Week & Total (100\%) \\
\hline Calf & $89 \cdot 0 \%$ & $8 \cdot 8 \%$ & $0 \cdot 7 \%$ & $1 \cdot 5 \%$ & 136 \\
Hamstrings & $84 \cdot 9 \%$ & $6 \cdot 8 \%$ & $5 \cdot 5 \%$ & $2 \cdot 8 \%$ & 73 \\
Quadriceps & $68 \cdot 5 \%$ & $6 \cdot 8 \%$ & $16 \cdot 4 \%$ & $8 \cdot 3 \%$ & 73 \\
Back extensors & $7 \cdot 5 \%$ & - & $1 \cdot 5 \%$ & - & 8 \\
Ankle joint & $90 \cdot 4 \%$ & $3 \cdot 8 \%$ & $5 \cdot 8 \%$ & - & 104 \\
Knee joint & $76 \cdot 1 \%$ & $12 \cdot 5 \%$ & $5 \cdot 1 \%$ & $6 \cdot 3 \%$ & 32 \\
Hip joint & $33 \cdot 3 \%$ & $66 \cdot 7 \%$ & - & - & 3 \\
Wrist joint & - & $100 \%$ & - & - & 2 \\
Spine & $100 \%$ & - & - & - & 3 \\
\hline
\end{tabular}

knee $(22 \cdot 2 \%)$, hip $(2 \%)$, spine $(2 \%)$, and wrist $(1 \cdot 38 \%$ ) (table 5 ).

INJURY

Incidents of joint injury most commonly involved the ankle $(37 \cdot 9 \%)$. This was followed by the knee $(26 \cdot 3 \%)$. Other joints involved in injury incidents included the hip $(1.4 \%)$ and the wrist $(3.2 \%)$. Unlike pain, the greatest number of incidents of injury was recorded in the second week. Males $(74 \cdot 7 \%)$ were more injury-prone than females $(45.5 \%)$ (table 6 ). Ligaments $(65.8 \%)$ were more predisposed to injury than tendons $(19.9 \%)$ and intraarticular injuries $(14 \cdot 3 \%)$. This is shown in table 7.

\section{JOINT SWELLING}

Females $(82 \cdot 2 \%)$ experienced more joint swelling than their male $(17 \cdot 8 \%)$ counterparts, with the ankle joint being the most commonly affected. This is shown in table 8.

RATING OF PAIN

The majority $(67 \cdot 3 \%)$ of the subjects rated their pain as severe, $29.3 \%$ rated it as moderate while only $8 \cdot 1 \%$ rated it as mild (table 9 ).

\section{Discussion}

From table 2, it can be seen that graduates of higher institutions of learning in Nigeria (potential subjects) are physically unfit. This corroborates the findings of Onifade ${ }^{8}$ and Onifade and Okuneye, ${ }^{9}$ who obtained similar

Table 4 Sex variation in the weekly distribution of muscular pain following intense physical training in non-athletic youth corpers.

\begin{tabular}{|c|c|c|c|c|c|c|c|c|c|c|c|c|c|}
\hline \multirow{2}{*}{$\begin{array}{l}\text { Muscle } \\
\text { groups }\end{array}$} & \multicolumn{3}{|c|}{ 1st Week } & \multicolumn{3}{|c|}{ 2nd Week } & \multicolumn{3}{|c|}{ 3rd Week } & \multicolumn{3}{|c|}{ 4th Week } & \multirow{2}{*}{$\begin{array}{l}\text { Per cent } \\
\text { of total }\end{array}$} \\
\hline & Male & Female & Total & Male & Female & Total & Male & Female & Total & Male & Female & Total & \\
\hline $\begin{array}{l}\text { Calf } \\
\text { Hamstrings } \\
\text { Quadriceps } \\
\text { Back extensors } \\
\text { Total }\end{array}$ & $\begin{array}{r}18 \cdot 3 \% \\
13 \cdot 3 \% \\
11 \cdot 1 \% \\
0 \cdot 7 \% \\
43 \cdot 4 \%\end{array}$ & $\begin{array}{r}23 \cdot 4 \% \\
7 \cdot 9 \% \\
6 \cdot 2 \% \\
1 \cdot 3 \% \\
38 \cdot 8 \%\end{array}$ & $\begin{array}{r}41 \cdot 7 \% \\
21 \cdot 2 \% \\
17 \cdot 3 \% \\
2 \cdot 0 \% \\
82 \cdot 2 \%\end{array}$ & $\begin{array}{l}1 \cdot 7 \% \\
0 \cdot 7 \% \\
1 \cdot 0 \% \\
3 \cdot 4 \%\end{array}$ & $\begin{array}{l}2 \cdot 5 \% \\
1 \cdot 0 \% \\
0 \cdot 7 \% \\
4 \cdot 2 \%\end{array}$ & $\begin{array}{l}4 \cdot 2 \% \\
1 \cdot 7 \% \\
1 \cdot 7 \% \\
7 \cdot 6 \%\end{array}$ & $\begin{array}{l}- \\
1 \cdot 1 \% \\
3 \cdot 4 \% \\
0 \cdot 35 \% \\
4 \cdot 85 \%\end{array}$ & $\begin{array}{l}0.35 \% \\
0.3 \% \\
0.7 \% \\
0.35 \% \\
1.7 \%\end{array}$ & $\begin{array}{l}0 \cdot 35 \% \\
1 \cdot 4 \% \\
4 \cdot 1 \% \\
0 \cdot 7 \% \\
6 \cdot 55 \%\end{array}$ & $\begin{array}{l}0.35 \% \\
0.9 \% \\
1.8 \% \\
-3.05 \%\end{array}$ & $\begin{array}{l}0 \cdot 35 \% \\
\overline{0} \\
\overline{0} 3 \% \\
0 \cdot 65 \%\end{array}$ & $\begin{array}{l}0.7 \% \\
0.9 \% \\
2 \cdot 1 \% \\
3 \cdot 7 \%\end{array}$ & $\begin{array}{r}46 \cdot 9 \\
25 \cdot 2 \\
25 \cdot 2 \\
2 \cdot 7 \\
100\end{array}$ \\
\hline
\end{tabular}

Table 5 Sex variation in the weekly distribution of joint pain following intense physical training in non-athletic youth corpers.

\begin{tabular}{|c|c|c|c|c|c|c|c|c|c|c|c|c|c|c|}
\hline \multirow[t]{2}{*}{ foint } & \multicolumn{3}{|c|}{ 1st Week } & \multicolumn{3}{|c|}{ 2nd Week } & \multicolumn{3}{|c|}{ 3rd Week } & \multicolumn{3}{|c|}{ 4th Week } & \multirow{2}{*}{$\begin{array}{l}\text { Grand } \\
\text { total }\end{array}$} & \multirow{2}{*}{$\begin{array}{l}\text { Per cent } \\
\text { of total }\end{array}$} \\
\hline & Male & Female & Total & Male & Female & Total & Male & Female & Total & Male & Female & Total & & \\
\hline Ankle & $16 \cdot 7 \%$ & $46 \cdot 8 \%$ & $65 \cdot 3 \%$ & $2.0 \%$ & $0.7 \%$ & $2 \cdot 7 \%$ & $2 \cdot 8 \%$ & $1.4 \%$ & $4 \cdot 2 \%$ & - & - & - & 104 & $72 \%$ \\
\hline Knee & $14 \cdot 6 \%$ & $2 \cdot 8 \%$ & $17 \cdot 4 \%$ & $2 \cdot 1 \%$ & $0.9 \%$ & $2 \cdot 8 \%$ & $0.7 \%$ & - & $0.7 \%$ & $0.7 \%$ & $0 \cdot 7 \%$ & $1 \cdot 4 \%$ & 32 & $22 \cdot 2 \%$ \\
\hline Hip & $0.7 \%$ & - & $0.7 \%$ & $1 \cdot 3 \%$ & - & $1 \cdot 3 \%$ & - & - & - & - & - & - & 3 & 2 \\
\hline Wrist & - & - & - & - & $1 \cdot 38 \%$ & $1 \cdot 38 \%$ & - & - & - & - & - & - & 2 & $1 \cdot 38 \%$ \\
\hline Spine & $0.7 \%$ & $1 \cdot 3 \%$ & $2 \cdot 0 \%$ & - & & & - & - & - & & & - & 3 & $2 \%$ \\
\hline Total & $32 \cdot 7 \%$ & $52 \cdot 7 \%$ & $84 \cdot 4 \%$ & - & $1.98 \%$ & $7 \cdot 38 \%$ & $3.5 \%$ & $1.4 \%$ & $4.9 \%$ & $0.7 \%$ & $0 \cdot 7 \%$ & $1 \cdot 4 \%$ & 144 & $100 \%$ \\
\hline
\end{tabular}

Table 6 Weekly differences in the pattern of injuries in non-athletic youth corpers following intense physical training.

\begin{tabular}{|c|c|c|c|c|c|c|c|c|c|c|c|c|c|c|}
\hline \multirow{2}{*}{$\begin{array}{l}\text { Type of } \\
\text { injury }\end{array}$} & \multicolumn{3}{|c|}{ 1st Week } & \multicolumn{3}{|c|}{ 2nd Week } & \multicolumn{3}{|c|}{ 3rd Week } & \multicolumn{3}{|l|}{ 4th Week } & \multirow{2}{*}{$\begin{array}{l}\text { Grand } \\
\text { total }\end{array}$} & \multirow{2}{*}{$\begin{array}{l}\text { Per cent } \\
\text { of total }\end{array}$} \\
\hline & Male & Female & Total & Male & Female & Total & Male & Female & Total & Male & Female & Total & & \\
\hline Ankle joint & $17 \cdot 5 \%$ & $3 \cdot 5 \%$ & $21 \cdot 0 \%$ & $5 \cdot 3 \%$ & $2.4 \%$ & $7 \cdot 7 \%$ & $3 \cdot 2 \%$ & $1.7 \%$ & $4.9 \%$ & $3.6 \%$ & $0.7 \%$ & $4.3 \%$ & 108 & $37.9 \%$ \\
\hline Knee joint & $1.4 \%$ & - & $1.8 \%$ & $10.5 \%$ & $0.7 \%$ & $11 \cdot 2 \%$ & $3.4 \%$ & - & $3.9 \%$ & $8.4 \%$ & $1.0 \%$ & $9.4 \%$ & 75 & $26.3 \%$ \\
\hline Hip joint & - & - & - & $1 \cdot 1 \%$ & - & $1 \cdot 1 \%$ & $0.3 \%$ & - & $0 \cdot 3 \%$ & - & - & - & 4 & $1.4 \%$ \\
\hline Wrist & & - & - & $0.35 \%$ & $1 \cdot 75 \%$ & $2 \cdot 1 \%$ & - & $0.35 \%$ & $0.35 \%$ & $0.35 \%$ & $0 \cdot 35 \%$ & $0.7 \%$ & 9 & $3.2 \%$ \\
\hline Bruises & $5 \cdot 6 \%$ & $1 \cdot 4 \%$ & $7 \cdot 0 \%$ & $11 \cdot 2 \%$ & $3.9 \%$ & $15 \cdot 1 \%$ & $4 \cdot 6 \%$ & $0.7 \%$ & $5 \cdot 3 \%$ & $1 \cdot 4 \%$ & $2 \cdot 5 \%$ & $3.9 \%$ & 89 & $31 \cdot 2 \%$ \\
\hline Total & $24 \cdot 5 \%$ & $5 \cdot 3 \%$ & $29 \cdot 8 \%$ & $28 \cdot 4 \%$ & $8 \cdot 8 \%$ & $37 \cdot 2 \%$ & $11.9 \%$ & $2 \cdot 8 \%$ & $14 \cdot 7 \%$ & $13 \cdot 7 \%$ & $4 \cdot 6 \%$ & $18 \cdot 3 \%$ & 285 & $100 \%$ \\
\hline
\end{tabular}


Table 7 Structural involvement of injury following intense physical training among non-athletic youth corpers.

\begin{tabular}{|c|c|c|c|c|c|c|c|c|c|c|}
\hline \multirow[t]{2}{*}{ foint } & \multicolumn{3}{|l|}{ Tendon } & \multicolumn{3}{|c|}{ Ligaments } & \multicolumn{3}{|c|}{ Intra-articular problems } & \multirow{2}{*}{$\begin{array}{l}\text { Grand } \\
\text { total } \\
\text { (100\%) }\end{array}$} \\
\hline & Male & Female & Total & Male & Female & Total & Male & Female & Total & \\
\hline $\begin{array}{l}\text { Ankle } \\
\text { Knee }\end{array}$ & $\begin{array}{r}13.9 \% \\
6.7 \%\end{array}$ & $\begin{array}{l}5.5 \% \\
1.3 \%\end{array}$ & $\begin{array}{r}19.4 \% \\
8.0 \%\end{array}$ & $\begin{array}{l}42.6 \% \\
70.6 \%\end{array}$ & $\begin{array}{r}25.9 \% \\
2.7 \%\end{array}$ & $68.5 \%$ & $\begin{array}{r}9.3 \% \\
\end{array}$ & $2 \cdot 8 \%$ & $12 \cdot 1 \%$ & 108 \\
\hline Hip & $100 \%$ & - & $100 \%$ & - & - & $12.3 \%$ & $12 \cdot 0 \%$ & - & $18 \cdot 1 \%$ & $\begin{array}{r}13 \\
4\end{array}$ \\
\hline Wrist & $22 \cdot 2 \%$ & $66 \cdot 7 \%$ & $88.9 \%$ & - & - & - & - & $11 \cdot 1 \%$ & $11 \cdot 1 \%$ & 9 \\
\hline
\end{tabular}

results among University undergraduates. The implication of this is that they have low muscular and cardiorespiratory endurance, and hence should be conditioned gradually to full physical fitness level. Nevertheless they were exposed to the sudden intense exercise, drill and games on arrival in camp. This would explain the high incidence of severe pain among the subjects.

Males are believed to be more physically adventurous in general than female ${ }^{10}$; hence subjecting both sexes to the same exercise regime places relatively more stress on the nonathletic female than the more athletic male, thus explaining why females complained of more pain $(100 \%)$ and less injury $(54.5 \%)$, unlike the males who recorded more injury $(74 \cdot 7 \%)$ and less pain $(52 \%)$.

The ankle was found to have the highest incidence of pain $(72 \cdot 2 \%)$, injury $(37 \cdot 9)$, and swelling $(23.7 \%)$. This supports Bass, ${ }^{11}$ Wilson, ${ }^{12}$ and Adedoyin's earlier finding ${ }^{6}$ that the ankle is more predisposed to injury than other joints. However, this is in contrast to the findings of Salmon, ${ }^{13}$ Adeniran and Toriola, ${ }^{3}$ and Adeniran ${ }^{4}$ who found that injuries to the knee predominated. That the ankle and knee joints should be the prime joints involved on the injury following unaccustomed exercise is hardly surprising. These two joints are both weight bearing structures in nearly all human activities carried out in the erect position. ${ }^{2}$ However, the skilled activities of kicking and ball manipulation (as in soccer) and the effect of ground reaction and shoe types and fitting (as in physical drills and other exercises) appear to have a direct impact on the ankle joint, which is closer to the ground than the knee.

Ekstrand and Gilquist ${ }^{14}$ observed that the range of movement and the tensile strength of the ligaments and tendons holding the joints is improved by flexibility training and that

Table 8 Sex distribution of joint swelling among non-athletic youth corpers following intense exercise.

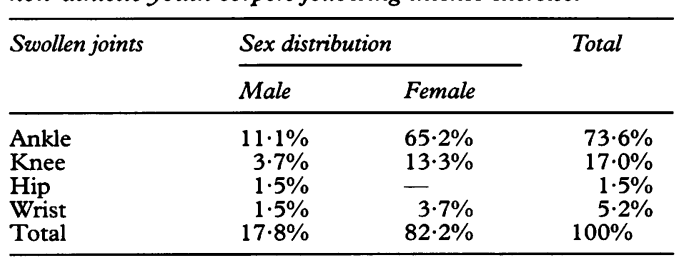

flexible joints are less susceptible to sports injuries. Thus the sudden change in the intensity of work without previous specific flexibility training might be responsible for the high incidence of joint injuries, swelling and pain observed in this study, the ankle being the most affected.

That the lower limbs were more affected by pain and injury is to be expected. This is because a direct relation had been established between the athletes' lower limb muscle strength and susceptibility to injury. ${ }^{15}$ Klein and Allman ${ }^{16}$ proposed that the muscular strength of the hamstrings, in proportion to the quadriceps in both lower limbs, should be equal to or greater than $69 \%$ in order to prevent hamstring injury, especially in contact sports requiring rapid explosive movements such as soccer. ${ }^{2}$ This strength ratio would be unusual in untrained youths. Also, the mechanism of lactic acid buffering and removal is more efficient in trained than untrained athletes. ${ }^{17}$ In the latter, lactic acid and other products of metabolism accumulate faster, and fatigue sets in sooner, thus affecting reaction time. ${ }^{18}$ The inability of the untrained muscle to relax, coupled with the reduced ability to respond to external stimuli, could have (directly or indirectly) contributed to the high rate of injury observed in this study.

This also explains the finding that the incidence of injury peaked at the second week of training when contact sport (soccer) started. This result is also consistent with other reports $^{245}$ that the greatest incidence of injury occurs at the beginning of training and practices. However, when considering the causes of injury, it should be noted that shoe selection and use are crucial factors, especially in running and drill. ${ }^{19}$

\section{CONCLUSIONS}

The following conclusions can be drawn from this study:

(1) Most undergraduates and new graduates in the camp are physically relatively unfit.

(2) The fitness programme designed for the camp subjects during the four weeks orientation period produced some adverse effects on their physical health.

(3) Sudden intense physical training (jogging, drills, calisthenics, contact games, "man o'war") caused discomfort and pain in untrained young people.

Table 9 Rating of perceived pain among non-athletic youth corpers following intense physical exercise.

\begin{tabular}{|c|c|c|c|c|c|c|c|c|}
\hline \multicolumn{3}{|l|}{ Mild } & \multicolumn{3}{|c|}{ Moderate } & \multicolumn{3}{|l|}{ Severe } \\
\hline Male & Female & Total & Male & Female & Total & Male & Female & Total \\
\hline$\stackrel{27}{6 \cdot 2 \%}$ & $\begin{array}{l}8 \\
1.9 \%\end{array}$ & $\begin{array}{l}25 \\
8 \cdot 1 \%\end{array}$ & $\begin{array}{l}76 \\
17 \cdot 5 \%\end{array}$ & $\begin{array}{l}51 \\
11 \cdot 8 \%\end{array}$ & $\begin{array}{l}127 \\
29 \cdot 3 \%\end{array}$ & $\begin{array}{l}217 \\
50 \%\end{array}$ & $\begin{array}{l}75 \\
17 \%\end{array}$ & $\underset{67 \cdot 3 \%}{292}$ \\
\hline
\end{tabular}


(4) The effect of the above form of fitness training is more severe in untrained females than males in terms of pain and exhaustion.

(5) Males are more injury-prone than females under these circumstances.

(6) Most injuries in non-athletic young people following the type of training described here are confined to the lower limbs.

(7) The ankle joint is their most vulnerable joint in the current context.

(8) The rate of injury/pain decreases as the fitness level improves following physical fitness training.

(9) Physical preparation of the subjects, say for 6-8 weeks before the camp, or a considerable reduction in the severity of the initial phase of the physical training in camp would go a long way in solving or at least reducing these problems.

I wish to thank Chief and Mrs Timawus Mathias, Professor V C B Nwuga and Dr E O Uche-Nwachi for assistance during this work.

1 Messier SP, Pittalia KA. Aetiologic factors associated with selected running injuries. Med Sci Sports Exerc 1988; 20:501-5.

2 Balogun JA. Prevention of musculo-skeletal injuries in soccer - a conceptual approach. $\mathcal{F}$ Nigerian Assoc Sports $S c i$ Med 1990:40-5.

3 Adeniran SA, Toriola AL. Common Injuries among young Nigerian Athletes. Society for Indian National Institute of
Physical Education and Sports (SNIPES) Journal 1986;9: 58-65.

4 Adeniran SA. Prevalent injuries among Nigerian Youth Soccer Players. $¥$ Nigerian Assoc Sports Sci Med 1990: $40-5$.

5 Olufemi EO. Soccer injuries and mode of rehabilitation among National League players in South Western Nigeria. Ile-Ife: National League players in South Western Nigeria.
Obafemi Awolowo University, 1990 [MSc Thesis].

6 Adedoyin S. Sports injury common among Nigerian Youth Corpers during orientation. Health Team 1993;3:5-7.

7 Balogun JA. Pain complaint and muscle soreness associated with high-voltage electrical stimulation: effect of ramp time. Percept Motor Skills 1986;62:799-810.

8 Onifade A. Students' rating of physical education teaching effectiveness. Nigeria Educ Forum 1984;9:293-8.

9 Okuneye RO, Onifade A. (1993) Factors affecting participation in higher institution sports. $\mathcal{f}$ Nigerian Assoc Sports Sci Med 1993:111-6.

10 Balogun JA, Abereoje OK. Pattern of road traffic accident cases in Nigeria University Teaching Hospital between 1987 and 1990. $f$ Trop Med Hyg 1992;95:23-9.

11 Bass AI. Injuries of the lower limb in football [abstr]. Proc $R$ Soc Med 1967;60:527.

12 Wilson JN. Specific injuries of sports [abstr]. 7 Chartered Soc Physiother 1972;58:194.

13 Salmon J. Recent experience in the treatment of some acute sporting injuries. Aust $\mathcal{F}$ Physiother 1967;113:103.

14 Ekstrand J, Gilquist J. Soccer injuries and their mechanism - a prospective study. Med Sci Sports Exerc 1982;15: - a prospec

15 Blackburn IA., Milne M., Dottolow H., Felder CD. Guideline for evaluation. Columbus, Georgia: Diversified Printing Services, 1979.

16 Klein K, Allman F. The knee in sports. Philadelphia: Austine Jenkins Publishing Co, 1971.

17 Costil DL, Coyle FE, Pink WE, Lesmes GR, Witzman FA. Adaptation in skeletal muscles following strength training. f Am Physiol Soc 1979:96-9.

18 Howard H, Poortmans JR. Metabolic adaptation to prolonged physical exercise. Maglingen, Switzerland: Research Institute, Federal School of Physical Education, 1975: 15-22.

19 Hamil J, Palty S, Freedson S, Boda W, Reidisman F. The effect of shoe type on cardio-respiratory responses and effect of shoe type on cardio-respiratory responses and
rear foot motion during treadmill running. Med Sci Sports Exerc 1988;20:515-21. 